\title{
LA MELANCOLÍA DE IZQUIERDA Y EL UTOPISMO ESPECTRAL ${ }^{1}$
}

\author{
CHRISTIAN RETAMAL \\ Universidad de Santiago de Chile. USACH
}

\begin{abstract}
RESUMEN: A partir de un escrito de Walter Benjamin se examina I) la noción de «melancolía de izquierda» para describir el estado emocional de los herederos del marxismo. Para ello II) se explora cómo la melancolía del romanticismo es sublimada en el marxismo y emerge luego de su crisis opacando su impulso utópico. III) Posteriormente se analizan las paradojas presentes en algunas representaciones de la melancolía para mostrar las tensiones religiosas presentes en el utopismo y cómo estas se trasladan a la visión de mundo de las izquierdas. IV) Este análisis nos muestra - desde un punto de vista psicoanalítico - la necesidad de considerar la muerte de las abstracciones equivalentes propia de la melancolía para averiguar que es aquello que ha muerto en el pensamiento de izquierdas. Finalmente V) se plantea que el modo en que se concibe y desarrolla la subjetivad fuerte en la cultura moderna es la base de la melancolía de izquierda y por ello es la puerta de salida de tal condición.
\end{abstract}

PALABRAS CLAVE: Marxismo, Walter Benjamin, Durero, modernidad, subjetividad.

\section{Melancholy left and spectral utopianism}

ABSTRACT: From a review of Walter Benjamin discussed I) the notion of "left melancholy" to describe the emotional state of the heirs of Marxism. To do II) explores how the romantic melancholy is sublimated in Marxism. Then how this melancholy returns overshadowing his utopian impulse. III) After the paradoxes of some representations of melancholia are analyzed to show the religious tensions in utopianism and how these are transferred to the worldview of the left. IV) This analysis shows, from a psychoanalytic point of view, the need to consider the death of the "equivalent abstractions" own melancholy, to find out what is it that has died in leftist thought. Finally V) the way it is conceived and developed strong subjetivad in modern culture is observed is the basis of melancholy left and it is the exit of such a condition.

KEY WORDS: Marxism, Walter Benjamin, Dürer, modernity, subjectivity.

\section{INTRODUCCIÓN}

Uno de los temas más relevantes y al mismo tiempo más desatendido es el tipo de emociones que las distintas orientaciones políticas expresan en base a sus perfiles ideológicos. Dicho tema fue recurrentemente abordado por la sociología del conocimiento desde la obra inaugural Ideología y utopía (1929) de Karl Mannheim. En este sentido, la tonalidad emocional se abordó como una cuestión de identidad que enlazaba tanto lo colectivo como lo personal en un cauce relativamente coherente y disponible para la acción política. Sin embargo, el sustrato emocional de la política fue dejado de lado al primar enfoques más instrumentales, sistémicos o simplemente racionalistas. Creemos que es necesario volver la mirada sobre este campo ya que la política es evidentemente también una cuestión que moviliza — para bien o para mal- emociones. En el caso de las izquierdas su tono emocional tradicionalmente estuvo marcado por la fuerza de la voluntad fundada en el optimismo en el progreso y su teleología implícita, como queda

\footnotetext{
1 Este artículo forma parte del proyecto FONDECYT 1130903 y del proyecto DICYT $031653 \mathrm{RH}$.
} 
ejemplificado en el famoso cuadro La Libertad guiando al pueblo pintado por Eugène Delacroix en 1830. El campo semántico propio de la izquierda estuvo marcado por las nociones de esperanza, progreso, revolución, utopía.

Sin embargo, el panorama actual de la izquierda heredera del marxismo no encaja con la visión antes descrita. Incluso para aquellos que abogan por una interpretación de la situación actual bajo los paradigmas posmodernos la melancolía sirve de núcleo de articulación frente al optimismo de la modernidad. Sin embargo, la melancolía ya estaba presente en los análisis de Walter Benjamin. En efecto, el término «melancolía de izquierda» fue acuñado como título de una reseña homónima que el autor hizo de un libro de poemas de Erich Kästner en 1931 ( «Left-Wing Melancholy») 2.

Allí Benjamin fustiga la obra de Kästner —uno de los intelectuales más representativos de la República de Weimar- y la acusa de ser producto y representación de una melancolía muy especial que sufre una parte de la intelectualidad de izquierda. Esta melancolía tiene como consecuencia dejarse llevar por el pesimismo existencial, nutrirse y gozar de una «insana tortura» que se manifiesta en un radicalismo intelectual cercano al nihilismo y que conduce a la inacción política. La mirada de Benjamin en este texto es más cercana al debate político que a la crítica literaria, ya que lo que está en juego — según su perspectiva - es el modo en que la intelectualidad de izquierda se relaciona con la política. La dura crítica a Kästner es una respuesta a una intelectualidad que crea objetos banales para el consumo de la cultura de masas que pretenden tener una impronta progresista, pero que carecen de valor revolucionario (Benjamin, 1974: 29). En ese sentido Benjamin indica que esta «inteligencia radical de izquierdas» desde el punto de vista político crea clichés en vez de partidos, en el campo de la literatura crea modas en vez de escuelas y en la esfera económica se dirige a «agentes» y no a los productores (trabajadores).

Benjamin señala cómo en la poesía de Kästner la melancolía y la insatisfacción están basadas en el peso de la rutina y el aburrimiento que hace que incluso su ironía y rebuscado lenguaje lleguen a ser rutinarios. Por ende su relación con el mundo de lo político se basa en la subestimación del adversario y en la búsqueda de la entretención donde el arte mismo se convierte en mercancía. De allí que compare desfavorablemente a Kästner con Bertolt Brecht. En un plano más general Benjamin acusa a este radicalismo de izquierda de completa ineficacia política, ya que se sitúa "a la izquierda de cualquier posibilidad», ya que su ethos se caracteriza por el ensimismamiento en una calmada negatividad ante el mundo. Ello conduce a que su desarrollo intelectual gire en torno a la crítica sin tener la capacidad de articular propuestas. Para el autor este nihilismo es una variante de la desesperación que se destaca por el cultivo de la «estupidez atormentada», siendo la última metamorfosis de la melancolía tras dos mil años de historia (Benjamin, 1974: 30). Como vemos la crítica de Benjamin es tajante, despiadada y no teme involucrarse en la coyuntura.

La importancia de haber abarcado las características del ethos cultural de la izquierda en dicho concepto se debe a que Benjamin penetró profundamente en la melancolía al construir su genealogía en El origen del drama barroco alemán y en sus Fragmentos sobre la historia ${ }^{3}$. El concepto de melancolía de izquierda ha sido rescatado, varias déca-

2 Benjamin siguió desarrollando el aspecto literario de su crítica a Kästner en «El autor como productor» (1975) y en un sentido más amplio como diagnóstico de una época en los albores de la II Guerra Mundial en «Informe sobre la literatura francesa» (2008).

3 Aquí nos guiaremos por la versión crítica contenida en La dialéctica en suspenso. Fragmentos sobre la historia (2000). Un desarrollo más específico de este punto en BucK-Morss (1981) y BERNSTEIN (1998). Para una discusión sobre el estilo de Benjamin en el contexto de su generación ver los trabajos de NorRIS (1983), Pensky (1993) y Best (2012). 
das después, para describir el profundo impacto emocional provocado por el derrumbe del socialismo real en la cultura y lo que queda después de la presunta muerte de la utopía. David Gross utilizó esta imagen para vincularla al declive de las ideas progresistas de fines del siglo xx implicando al conjunto de las opciones políticas modernas, incluido el sujeto liberal (Gross, 112-121). Por su parte, Serra y García Selgas retomaron el concepto para su reinterpretación en el contexto de la crisis de la izquierda tras la caída del muro de Berlín y lo que supuso para el socialismo en general (García Selgas y Serra, 35). Similar enfoque utiliza Helmut Dubiel poniendo énfasis en la reacción de la intelectualidad de izquierdas (Dubiel 241-249).

En un sentido más amplio Martin Jay también reutilizó el concepto desde una óptica culturalista (1992) y Stuart Hall, por su parte, estudió las condiciones que llevaron a la fundación de la Nueva Izquierda como respuesta al despotismo soviético (210). Wendy Brown reorientó el concepto para abarcar las democracias liberales y las contrariedades que supone para la política liberal hacerse cargo de renovar la idea de progreso (Politics out of history), cuestión retomada luego por Adrian Little (2010). Christian Gundermann, por su parte, extrapoló el concepto de melancolía de izquierda y lo reelaboró como un efecto traumático de las dictaduras militares en América Latina (Actos melancólicos. Formas de resistencia en la posdictadura argentina, 2007). George M. Shulman, en cambio, ha usado el concepto en el contexto de la política imperial estadounidense y sus implicaciones para la globalización (American Prophecy. Race and Redemption in American Political Culture, 2008). Por otra parte, esta idea - como tono cultural amplio- ha sido utilizada para indagar en la licuefacción del marxismo y el mundo de izquierdas en general (Konder 1999. Jameson 2009. Scribner 2003).

Como puede verse esta influencia ha sido perdurable a pesar de que se trata de un concepto aparecido en una reseña menor y poco conocida. Su impacto radica en haber tocado una realidad de la cultura de izquierda de un modo ciertamente inquietante para quienes se sienten identificados con ella. En este sentido nuestro objetivo en este texto es analizar la melancolía de izquierda como una afección de la subjetividad moderna que se origina en las paradojas creadas por la importancia del utopismo. Dicha importancia la podemos rastrear en la larga duración histórica del pensamiento de las diversas izquierdas, especialmente las ramas derivadas del marxismo. Vemos una relación tensa entre el auge y posterior crisis del pensamiento utópico de izquierdas y la melancolía de izquierda como respuesta ante la imposibilidad de concretar el contenido de sus utopías. En consecuencia, responder a la resaca utópica del último siglo es una tarea ineludible para recomponer el pensamiento de izquierdas y salir del estado melancólico.

\section{LA MELANCOLÍA ROMÁNTICA Y SU VÍNCULO CON EL MARXISMO}

La melancolía ha sido objeto de estudio desde muy antiguo y llama la atención la unidad de significado que ha tenido durante siglos. En castellano el Nuevo tesoro lexicográfico de la lengua española (NTLLE) nos informa que ya en 1607 aparece el lema Melancolía con prácticamente las mismas características que hoy le asigna el diccionario de la RAE, lo cual resulta muy interesante. Se le asocia a la presencia de la bilis negra (Atrabilis) que produce «una tristeza vaga, profunda, sosegada y permanente, nacida de causas físicas o morales, que hace que el sujeto no pueda encontrar gusto ni diversión en ninguna cosa». Igualmente se destaca el carácter obsesivo (monomaniaco) en que «dominan las afecciones morales tristes». La clásica obra de Richard Burton Anatomía de la melancolía escrita entre 1621 y 1652 abunda en esta descripción y rastrea de forma 
enciclopédica, obsesiva y como autoanálisis, los distintos derroteros de la melancolía. También podríamos remontarnos al propio Hipócrates y Aristóteles, pero entendemos que una visión histórica de la melancolía resulta aquí imposible e innecesaria al existir obras contundentes como Saturno y la melancolía (1964) de Klibansky, Panofsky y Saxl.

Como ya se ha indicado, quisiéramos apuntar a la melancolía como afección de la subjetividad. En efecto, parte importante de la caracterización de la modernidad, independientemente de sus vertientes filosóficas, consiste en afirmar el primado de una subjetividad en sentido fuerte que es capaz de asumir la vida como un proyecto guiado por la razón. Como se sabe la raíz del término «sujeto» proviene del latín subiic re que significa "poner debajo, someter» lo que implica una entidad caracterizada por una voluntad de poder. Recordemos que lo que se pretende someter es la naturaleza en una doble acepción; la naturaleza interior entendida como las propias pasiones y los deseos que tienen una dinámica inconmensurable $\mathrm{y}$, por otra parte, la naturaleza exterior representada por los estados de privación en un mundo percibido como amenazante y que debe ser dominado en un proceso de creciente domesticación. La domesticación del mundo y de sí mismo es una acción de despliegue del ser humano en que la vida se presenta como acción y proyecto. En efecto, la naturaleza humana misma es entendida como acción transformadora y productiva que puede evaluarse por lo que llega a ser, y no por lo que se posee. En eso podemos encontrar un consenso que va desde Spinoza a Benjamin pasando por Hegel, Goethe y Marx ${ }^{4}$.

En efecto, como destaca Fromm en su análisis de los Manuscritos Económico-Filosóficos de Marx $(2005,40)$ existe un fuerte énfasis en el carácter positivo de entender la vida como una tarea y un proyecto, lo cual permite ir reduciendo la distancia entre lo que se entiende como la esencia humana y su existencia concreta. En este sentido los Manuscritos no serían una excepción de la corriente principal de la modernidad respecto de este punto, sino una expresión más acabada que apunta a su expresión real. Dicho de otro modo, al observar — por ejemplo - la subjetividad aprisionada por el dinero ésta se manifiesta tanto en su aspecto concreto como en su aspecto esencial de formas eminentemente contrapuestas. Ello conduce a que la subjetividad humana exista en unas condiciones que impiden su manifestación real, por lo que la vida como tarea y proyecto se vuelve viable sólo en los estrechos marcos del trabajo alienado, recortando el potencial humano que para Marx resulta inconmensurable (Fromm 2005: 146). Y lo que aquí puede decirse de los individuos particulares puede señalarse también de la sociedad moderna en general, que a través de sus diversas corrientes políticas intenta encarnar el discurso del progreso.

Michael Löwy y Robert Sayre (1992) han descrito de manera contundente el desarrollo de la modernidad y su núcleo ilustrado y han mostrado cómo el romanticismo implicó una respuesta global a dicho núcleo que se expresó en campos tan disimiles como la poesía, las artes y la filosofía. Para los autores dicho enfrentamiento tiene una cara bifronte marcada tanto por la rebelión como la melancolía y ambos aspectos se combinan en medidas desiguales en romanticismos más específicos, que van desde el romanticismo conservador, restaurador y reformista al romanticismo jacobino, populista, libertario y también, aunque suene extraño, marxista. Lo que en el fondo Löwy y Sayre nos muestran es que el romanticismo constituye una extensa respuesta al avance

4 Z. BAUMAN, precisa que para Benjamin el sí mismo es algo que debe ser construido muy lentamente de modo que se llegue siempre a estar en el umbral de devenir uno mismo (Modernidad y ambivalencia 210). De este modo se recalca el aspecto utópico que tiene la construcción del sí mismo. 
de la civilización moderna, sus revoluciones industriales ${ }^{5}$, el mercado y en definitiva, parafraseando a Marx en el Manifiesto comunista, el continuo juego en que todo lo sólido se desvanece en el aire. De este modo la melancolía aparece integrada en una respuesta más amplia y profunda, pero no por eso más clara o enmarcada en un programa político definible. Si el romanticismo muestra la amplitud antes señalada, eso también afecta a uno de sus rasgos definitorios como lo es la melancolía. En consecuencia, podemos indicar que a cada uno de los romanticismos no sólo correspondería una distinta dosis de la atrabilis o bilis negra que caracteriza a la melancolía, sino que la misma tendría matices diferentes.

En el caso del marxismo, como indican los autores citados, la actitud hacia el romanticismo y por derivación respecto de la melancolía es de ambivalencia, lo que se debe a la influencia de la Ilustración en las diversas ramas del marxismo. Los autores reconocen que tanto Marx como muchos de sus discípulos fueron capaces de integrar de manera eficiente la crítica romántica a la modernidad, de modo que la rebelión ante el nuevo orden emergente fue incluida en la imagen de la revolución. De este modo el conjunto de emociones generadas por la sensación de pérdida del pasado de supuesta confraternidad comunal fue reorientado a un deseo de redención del futuro, por lo que el marxismo fue uno de los artífices principales en el cambio de la cronoestructura moderna.

En dicho proceso la melancolía de cuño romántico quedó ciertamente desfasada, porque la revolución se convirtió en una promesa de rescate y superación del pasado. La postración y el lamento melancólico dejaron de tener sentido en la medida que se ofrecía una salida que integraba las tensiones internas de la modernidad y les daba un nuevo sentido de trascendencia. Para que ello resultara se necesitaba poner en acción a la subjetividad de un modo que recogiendo la tradición moderna fuera más allá, ya que como el mismo Marx había indicado en su célebre tesis XI sobre Feuerbach de lo que se trataba era de transformar el mundo, ya que la simple labor de interpretarlo era insuficiente.

Por ende lo que hoy vemos como un inusitado voluntarismo - que por cierto no es sólo aplicable al marxismo- tiene una dimensión más profunda en que la subjetividad se lanza al mundo con una vocación trasformadora y convencida de que puede disponer de los elementos para una tarea prometeica. Son muchos los hitos que muestran cómo la acción política, a pesar de la adversidad, crea nuevas realidades. Esto queda de manifiesto en las formaciones de las Internacionales obreras, el advenimiento del leninismo como una nueva tecnología de lo político, o la ampliación de la base filosófica y social del marxismo que incluso absorbe a sus antiguos compañeros de ruta. Todo ello va conformando lo que Ernst Bloch denominó la subjetividad militante que, en resumen, implica la encarnación en la vida cotidiana de una visión utópica que da sentido, relato y unidad existencial.

Sin embargo, como señala Perry Anderson en sus Consideraciones sobre el marxismo occidental (p. 94), a partir de la segunda década del siglo pasado la energía del marxismo clásico comenzó a agotarse justamente cuando se producía su mayor éxito; la consolidación de la URSS. Las terribles experiencias de la I Guerra Mundial, la transformación totalitaria de la Revolución de Octubre, la ausencia de otro foco revolucionario en Europa y posteriormente el ascenso del fascismo y el nazismo centraron sus preocupaciones en aspectos totalmente nuevos. Anderson indica como factor esencial de esta nueva

\footnotetext{
5 Para una específica reflexión sobre la importancia de la revolución industrial, el cambio urbano y la melancolía en la obra de Benjamin ver CAYGILL (1998).
} 
generación de marxistas — de la cual forma parte Benjamin y la totalidad de la Escuela de Frankfurt entre otros- la desconexión entre su actividad teórica y su vida militante. Para el autor este no es un problema meramente biográfico, ya que la epistemología marxista supone la existencia de una relación fluida entre una teoría revolucionaria y una actividad política tal que permita una sana sinergia entre ambas.

Anderson rastrea a cada uno de los autores marxistas europeos relevantes en la primera mitad del siglo xx y señala la desproporcionada cantidad de filósofos y académicos en desmedro de otras miradas más vinculadas al análisis empírico en la sociología, la economía, la historia y especialmente el análisis político. Esto trajo como consecuencia un predominio especulativo que favoreció la emergencia, por ejemplo, de la estética marxista y un análisis de la cultura burguesa convertida ahora en cultura de masas ${ }^{6}$. Ello en desmedro de un estudio más específico de la cultura obrera en particular, salvo en Inglaterra, así como una mezcla con otras corrientes de pensamiento como el psicoanálisis y la teoría sociológica weberiana.

Este desarraigo de la vida política activa y contingente supuso un giro culturalista en el marxismo occidental que prevalece hasta hoy y que para Anderson tiene un componente más profundo. En efecto, más allá de los matices que separan a los diversos exponentes del marxismo occidental lo que los une es un profundo tono emocional pesimista a diferencia de sus predecesores del marxismo clásico (Anderson: 110). La melancolía, para Anderson, es una nota característica de la Escuela de Frankfurt y también de la obra de Benjamin, que usan un lenguaje impensado para el entorno más inmediato a Marx. En este sentido tanto el pesimismo como la melancolía son una corriente subterránea de este nuevo marxismo que lo ira modelando en las décadas venideras y que se acentuará finalizada la II Guerra Mundial. En efecto, el talante romántico, y su matiz específicamente melancólico, que el marxismo clásico había integrado de manera eficiente parece haberse desencajado de una visión unitaria de la realidad como un proyecto a concretar. Como señala Anderson, los intelectuales ligados al marxismo occidental se formaron en la derrota, con plena conciencia de los problemas que implicaba el socialismo en la URSS, además vieron con estupefacción el surgimiento del fascismo y luego la notable capacidad de reinvención del capitalismo ${ }^{7}$.

El origen de la condición melancólica del marxismo occidental estaría entonces, en principio, en la derrota política tanto frente a los adversarios externos como a nuevos adversarios internos representados por la cultura del estalinismo. Ello puso en jaque al impulso utópico propio del marxismo clásico afectando centralmente su noción de subjetividad fuerte. De este modo la melancolía puede entenderse ante todo como una incapacidad de la subjetividad para realizarse, como una potencia que se vuelca a la transformación racional del mundo desde una perspectiva socialista y emancipadora, pero que reintroduce nuevas formas de dominación.

En este contexto cobra sentido la expresión «melancolía de izquierda», acuñada por Benjamin, que describe el radicalismo y nihilismo de izquierdas de la época de la República de Weimar y que luego se ha extendido para designar una modalidad de crisis de la izquierda extensible al conjunto de la modernidad. Resulta evidente la particular afinidad entre Benjamin y Anderson para explicar el estado emocional de la izquierda, particularmente en cuanto a su ineficiencia política y su tendencia a la especulación. Parece una obviedad señalar que tanto el conservadurismo y el liberalismo no parecen estar en crisis

6 Es interesante contrastar la perspectiva de Anderson con la de BucK-Morss (2000).

7 Un interesante análisis sobre la crisis del socialismo expresado en la cultura y el arte lo podemos encontrar en ERJAVEC (2003) y desde una mirada más amplia en JAMESON (1998). 
al modo en que lo están las diversas izquierdas, al menos no en cuanto a su tono emocional. Al contrario, su auge y euforia es correlativo a los estertores de su adversario histórico. La melancolía de izquierda tiene una dimensión más importarte que ser expresión de una crisis de amplias repercusiones en el ámbito de las alternativas políticas modernas. Dicha condición se revela como una crisis de la propia subjetividad moderna, y particularmente como un agotamiento de las fuerzas emancipadoras radicadas en la herencia de la Ilustración y en los diversos utopismos. El centro de dicha melancolía es justamente el agotamiento del utopismo tal cual lo hemos conocido y su filosofía de la historia.

\section{LOS ÁNGELES MELANCÓLICOS}

El utopismo del marxismo se basa, como hemos indicado, en la idea de un progreso teleológicamente orientado, pero que desborda a quienes lo han puesto en marcha y también a quienes pretenden comandarlo. Pero lo que acontece como catástrofe no es sólo algo que implique a la visiones de izquierdas, sino que también abarca al conjunto de la modernidad independientemente de la matriz ideológica sobre la que se articule.

Benjamin lo graficó recurriendo a la imagen del ángel de la historia que retrocede ante el horror de la catástrofe en que se ha convertido el progreso (Benjamin, 2000: 53) y evoca indirectamente - como señala García y Serra (37) - el famoso grabado de Durero Melancolía I, como representación de este estado, que alude a una tristeza frente a la caducidad de las acciones humanas. El ángel de Durero, a diferencia del creado por Paul Klee que inspiró a Benjamin, está rodeado por símbolos que representan el mundo del conocimiento y la técnica humana que tienen poco sentido frente a la convicción de la superioridad de la naturaleza, en particular la acción devoradora del tiempo. Incluso la condición trascendental del ángel se manifiesta contradictoria en la situación representada, ya que mira en lo lejano el nombre de la melancolía intentando comprenderlo por medio del discurso que desganadamente escribe.

El ángel de Melancolía I de Durero* — como indica Doina Constantinescu (2000: 2)— es una notable expresión de la inacción melancólica ya que el conjunto del cuadro está dominado por la presencia del Dios Saturno también conocido como Kronos. Una deidad caníbal que devora a sus propios hijos y que también gobierna el tiempo y que luego se le asociará a la contemplación filosófica. Constantinescu, siguiendo a Panofsky, nos señala que el renacimiento fue prolífico en crear nuevas imágenes del tiempo como una entidad destructora personificada en Saturno. Para la autora, su poder reside en paralizar los sentimientos y afectos a través de una falta de energía característica de la condición melancólica. Constantinescu sigue una interpretación esotérica de la cual nos alejamos ya que fija su atención en los elementos cabalísticos, masones y mágicos entre otros. Sin embargo, su análisis da cuenta, al igual que el de Saturno y la melancolía (Klibansky, Panofsky y Saxl) de la intensa interconexión de los elementos del grabado en cuestión.

A nuestro modo de ver, Durero planteó su obra de manera que cada elemento particular sirviera de entrada holográfica a la totalidad de la obra. Ello provoca un peculiar efecto que es al mismo tiempo recursivo y sinérgico. El grabado está intensamente poblado de objetos alegóricos que aludiendo a sí mismos remiten recursivamente a los otros. Ejemplo de ello son los utensilios abandonados que apuntan a la inutilidad de un conjunto de actividades tanto artesanales, constructivas e intelectuales. Ello es claro en

\footnotetext{
Véase este grabado en la cabecera del editorial del presente número.
} 
las herramientas de construcción que evocan la potencia del trabajo manual, así como los objetos de medición del tiempo y del espacio, además de representaciones de objetos geométricos que apuntan a la abstracción pura y que ahora se ven carentes de sentido, ya que quién debe usarlos se encuentra en un estado de impotencia.

Tanto para Constantinescu (2000:7), como para Klibansky, Panofsky y Saxl (1991: 389) el ángel melancólico de Durero supone una suerte de renuncia humanística a la actividad en pos de la meditación y la contemplación. Sin embargo, nos parece que la actitud del ángel es otra. Su actitud manifiesta frustración en la medida que ha recorrido cada una de las actividades simbolizadas en el grabado. En este sentido, los objetos abandonados son suyos y testimonian que no han sido instrumentos adecuados para lograr lo que su dueño buscaba. Por ende los instrumentos, ya sea los de la abstracción geométrica — referencia a la matematización del mundo-, los de la construcción artesanal que permiten transformar la naturaleza en artificio y los esotéricos - que permitirían vislumbrar los misterio más profundos- parecen no abarcar lo que el ángel busca.

Nos parece que en este espacio intensamente recursivo hay un detalle llamativo: la presencia de dos relojes; uno de sol y otro de arena. Ambas representaciones del tiempo evocan significados bastante diferentes que añaden una tensión estructural al conjunto. El reloj de sol es una entrada holográfica que vincula la experiencia del sujeto a una dimensión cosmológica de un tiempo infinito, que en el caso de la melancolía no fluye como debiera. Es la presión del tiempo definida por Saturno tanto en su cara devoradora como trascendental. Esta visión coindice con la idea cristiana del tiempo sostenida en hitos trascendentes como la creación del mundo, la venida del Mesías y su crucifixión y el Apocalipsis. De modo que en el reloj de sol nos encontramos con una síntesis del tiempo cosmológico entendido como un ciclo infinito - detenido en este caso por la melancolía - y la visión lineal y progresiva del tiempo cristiano. Por otra parte, el reloj de arena es una entrada holográfica diferente que nos muestra el tiempo en una dimensión existencial, es decir el tiempo como algo que se nos acaba inexorablemente, culminando con la muerte, de modo que su fluir es siempre una pérdida. Así el reloj de arena es uno de los varios memento mori del grabado, pero en referencia al reloj de sol. Ambos relojes, como hemos indicado, son entradas holográficas sobre el mismo objeto, pero en sentidos diferentes (cosmológico y existencial) que amplifican una tensión no resuelta en la obra cuyo centro es el ángel.

Este reproduce dicha tensión en su relación con otro personaje secundario, el querubín, el cual representa la infancia en tanto promesa de una vida que comienza en contraposición con el agotamiento del ángel. Constantinescu (2000:19) interpreta al querubín como una imagen secundaria que representaría a la imaginación melancólica. Sin embargo, creemos que es más coherente ver al querubín y al ángel como la expresión del mismo sujeto en dos momentos y perspectivas vitales diferentes; la de la infancia inocente que tiene todo el mundo por estrenar y por ende se enfrenta a cada experiencia desde la novedad y la del individuo maduro - atrapado en la melancolíaque se dedica a la contemplación del mundo con cierta desidia y distancia, consciente de sus limitaciones y finitud. Nuestra diferencia con Constantinescu se profundiza en la medida que interpreta la oscuridad predominante del cuadro como una expresión infernal. Por el contrario, consideramos que la fuerza de la oscuridad es metáfora de la interioridad psicológica. La luz es acción divina o de la razón que proviene de fuera, de un Otro ausente. La luz interior en sus múltiples expresiones (alma, razón) se encuentra bloqueada por la inhibición frente a la acción que implica la melancolía Ello marca a un carácter como oscuro en donde el infierno sería la propia psiquis. 
En este sentido debemos hacernos cargo de la ambivalencia evidente de la iconografía de los ángeles como representación de una existencia trascendente, que gozan del acceso a la divinidad pero al mismo tiempo representan el otro extremo; la caída. En efecto, los ángeles representan en sí la ambigua relación de los humanos con el Dios del Libro (Judaísmo, Cristianismo e Islam). Una ambigüedad que va desde los sumisos súbditos, mensajeros y adoradores de Dios hasta los rebeldes, exiliados e iconoclastas.

Dicha ambivalencia alcanza a la figura de Durero, ya que a pesar de su postración el ángel es una buena representación de la imagen utópica que intenta reunir en sí la fuerza y determinación moderna por construir un mundo sólido. Pero tiene como una característica añadida la capacidad del vuelo, condición desde muy antiguo asociada a las deidades. Capacidad sobrehumana que sugiere el desprendimiento del suelo, como representación de la realidad que conocemos y que es superada por una nueva visión privilegiada del horizonte temporal. En este sentido, la figura angelical es una proyección radical de lo humano, que está impregnada de modernidad y que, por su misma condición existencial, tiene acceso al conocimiento de lo divino, y aun así sufre de melancolía. El ángel de Durero ha renunciado a la búsqueda de respuestas, no alza el vuelo. Por el contrario, su actitud es más cercana a la tierra, rodeado de sus objetos recientemente abandonados, porque se han manifestado como inútiles para la tarea de comprender y alterar la propia caducidad. Desde nuestro punto de vista, la representación se vuelve espectral porque lo que se contempla, paradójicamente, es la muerte de algo que no existe.

\section{LA MUERTE DE LAS ABSTRACCIONES EQUiVALENTES}

Para descifrar este enigma podemos recurrir a las categorías psicoanalíticas, ya que Freud describió la melancolía como la reacción a la pérdida de un ser amado existente y concreto y también como la pérdida inesperada e irrecuperable de una abstracción equivalente como la libertad, un ideal, etc. En tal sentido, la lista de abstracciones equivalentes que forman parte de la melancolía moderna es larga: los utopismos, el progreso, el relato de la Humanidad, etc. Estos elementos fueron las piedras angulares de la construcción de sentido social y personal y por ello ocupan un lugar privilegiado en el tono emocional melancólico. Freud señala en Duelo y Melancolía;

«la melancolía se caracteriza psíquicamente por un estado de ánimo profundamente doloroso, una cesación del interés por el mundo exterior, la pérdida de la capacidad de amar, la inhibición de todas las funciones y la disminución del amor propio». (1991:241)

En la melancolía, a diferencia del duelo, el principio de realidad se ve derrotado ya que el Yo se niega a aceptar que el objeto ha desaparecido cobrando un aspecto espectral. Por otra parte es nota característica de la melancolía una profunda perturbación del amor propio expresado en un importante empobrecimiento del Yo de quien la padece. En este sentido Freud nos indica que el melancólico se considera indigno de la estima social, incapaz de producir algo valioso y por ello se considera a sí mismo moralmente condenable. Otra diferencia notable entre el duelo y la melancolía es que en el primero se pierde realmente un objeto — claramente distinguible e independiente del Yo- mientras que en la melancolía la pérdida se ha producido en el propio Yo.

En efecto, una parte del Yo - la conciencia moral o Súper Yo- se sitúa enfrente de la otra y la crítica como si fuera un objeto (Freud, 1991: 245). Lo paradójico es que el individuo lleva a cabo una intensa autocritica que en realidad se dirige a otra persona o 
abstracción equivalente, pero en el contexto de la melancolía aparece como si estuviera radicada en su propio Yo. El resultado global es la postración y el debilitamiento de la pulsión propia de todo ser a mantenerse con vida, lo que puede terminar en el suicidio del melancólico.

Siguiendo a Freud, la muerte de los seres queridos o las abstracciones equivalentes son especialmente propicias para hacer surgir la ambivalencia de las relaciones amorosas. Dicha ambivalencia es mucho más amplia en la melancolía que en el duelo, ya que quien la padece experimenta la culpa de haber deseado la desaparición del objeto amado o incluso ser culpable de ella. En efecto, se desea mantener el amor al objeto amado - ahora ausente - pero dicho amor adopta una forma narcisista que se expresa en odio inconsciente al objeto. Ello produce una satisfacción sádica en el melancólico que se trasmuta en un placentero tormento de sí. Nótese que Benjamin utiliza una imagen semejante al referirse al ensimismamiento y el gozarse en una «insana tortura» que sólo puede ser calificada como estupidez atormentada.

En un duelo normal la realidad lentamente demuestra, ante la evocación de los recuerdos y esperanzas, la definitiva inexistencia del objeto. Eso acontece porque los recuerdos y esperanzas son los verdaderos puntos de contacto entre la libido y el objeto que deben ser cortados en el trabajo del duelo. Es aquí, ante tal evidencia de la realidad que el Yo decide abandonar sus lazos con el objeto si no quiere extinguirse con él, cuestión que no sucede con la melancolía debido a su ambivalencia inherente. Además esta ambivalencia hace que la melancolía pueda aparecer en muchas más ocasiones que el duelo, que se manifiesta ante pérdidas puntuales y concretas (Freud, 1991: 253).

En resumen, para Freud el núcleo de la melancolía radica en el proceso mediante el cual el sujeto elabora una investidura libidinal sobre un objeto, la que posteriormente se retrotrae al lugar del Yo del cual proviene. Esta retirada de la libido puede tornarse consciente como si fuera un conflicto entre una parte del Yo y la instancia crítica. Sin embargo, lo fundamental del proceso de la melancolía permanece oculto para quien la padece. Ello porque queda preso de la perspectiva del conflicto antes descrito, faltándole una perspectiva aérea que le dé acceso a una mirada de conjunto. En efecto, la melancolía tiene tres premisas básicas; la pérdida del objeto (la muerte de un ser querido o una abstracción equivalente), la ambivalencia de los vínculos amorosos y finalmente la regresión de la libido al Yo. Sabemos que las dos primeras aparecen en los procesos de muerte, mientras el tercero tiene una estrecha relación con el narcisismo y las necesidades que impone tal situación.

Desde nuestro punto de vista lo que nos interesa es la amplitud de esa ambivalencia característica de la melancolía, que hace que se manifieste en variadas situaciones y que, por ende, pueda desarrollarse a partir de múltiples abstracciones equivalentes. Como hemos visto a propósito del ángel melancólico de Durero la contradicción del grabado tiene que ver con una tensión no resuelta entre la visión de la trascendencia por una parte y la caducidad de las obras humanas, ya sean producto de la técnica, el conocimiento especulativo u otra. Creemos que en el grabado la tensión se ve aumentada por «el gran personaje ausente» a quién parece pedírsele cuentas por la paradoja de la situación. En efecto, Dios como el gran creador, superior al tiempo, se manifiesta aquí por la intensidad de su ausencia, ya que todo el discurso desplegado en Melancolía I es en realidad una interpelación de las criaturas al Creador.

Sin embargo, desde un punto de vista moderno nos resulta difícil sostener tales coordenadas de exploración, por lo que debemos preguntarnos cuál es el «el gran personaje ausente» que —como abstracción equivalente de los seres queridos- parece 
haber muerto desplegando como efecto la melancolía de izquierda. Cabe indicar que la superposición, propia del renacimiento, entre imágenes de deidades grecorromanas y cristianas crea situaciones interesantes como las aquí presentadas, ya que por una parte vemos a un Creador que dispone de un tiempo ilimitado, pero que inscribe en sus criaturas la finitud. De este modo se diría que Durero parece ver justamente en el dios cristiano el rostro de Saturno.

Como ya indicamos el utopismo cumple con ese perfil de «gran personaje ausente» en la medida que se ha constituido en la abstracción equivalente por antonomasia en donde se reúnen otros múltiples contenidos. En efecto, para la izquierda heredera del marxismo el utopismo siempre fue un contenido problemático en la medida que era el contenido reprimido de un ideal de sociedad. Sin embargo, a pesar del utopismo secreto y ambiguo de los padres del marxismo, éste era más bien objeto de vergüenza y pudor en la medida que se le identificaba con un modo de abordar la acción política de modo precientífico, moralista e ingenuo como quedó graficado en el texto «Del socialismo utópico al socialismo científico» de Engels. Pero esto no fue obstáculo para que se desarrollara una corriente cálida de tipo utópico — como lo describió Ernst Bloch (1977-80 Bloch, 1977-80: Vol. I 156) - en contraposición al frio marxismo de cuño empirista y siempre amarrado a las supuestas condiciones objetivas. En efecto, el utopismo también presenta una considerable ambivalencia interna de contenidos, aspiraciones que traspasan generaciones de modo que, como indica Bloch, existe un «clasicismo utópico» que recoge las aspiraciones vencidas del pasado que quedan en estado virtual para ser actualizadas por las luchas del futuro (Vol. I 115). Muchas veces se ha interpretado este clasicismo utópico como una especie de conservadurismo de izquierdas que se niega a aceptar las transformaciones de las últimas décadas, las insuficiencias teóricas del marxismo y las debilidades prácticas de los partidos y movimientos que se inspiraban en él (Brown, 1999: 25). Sin embargo aquí hay una línea sutil que distingue lo antes señalado de la necesidad de rescatar las energías y aprendizajes del pasado, lo cual permite también mantener una continuidad histórica que forma y da identidad ${ }^{8}$.

Así el utopismo se convierte en un eje articulador de las izquierdas, que gracias justamente a su ambivalencia, permite que muchos vean el reflejo de sus propios sueños al modo de cómo se integra los deseos particulares en una corriente más amplia que trasciende al individuo particular y efímero. Nótese que esto sería lo contrario a la melancolía de izquierda. Por el contrario, estaríamos en presencia de una acción transformadora animada por los deseos y una poderosa convicción de la potencia subjetiva. Es como si el ángel de Durero hubiera salido de su letargo y se hubiera puesto en marcha.

Evidentemente no se nos escapa que identificar al utopismo y Dios como los «personajes ausentes» de esta trama implica un conjunto de problemas, aunque tampoco es extraño este juego de superposiciones. El propio Benjamin jugaba con la idea del muñeco-autómata llamado "materialismo histórico», que era imbatible si era auxiliado por un enano en su interior llamado teología (Benjamin, 2000: 47). Desde un plano más general Karl Mannheim nos recuerda que lo que los filósofos ilustrados discutían en términos racionales la sociedad lo experimentaba como un conflicto religioso de ondas implicaciones psicológicas, cuestión que luego se trasladó a las formas modernas de la

8 Alain Badiou llama invariantes comunistas a estos elementos de continuidad como lo son «la pasión igualitaria, la idea de justicia, la voluntad de acabar con las componendas en el servicio de los bienes, la erradicación del egoísmo, la intolerancia ante la represión, el deseo de que el Estado desaparezca.» (2006: 19). 
política (Mannheim, 1993: 30). La modernidad creyó haber separado lo religioso de la esfera política a través de la racionalización, sin embargo, lo religioso siempre estuvo allí de modo difuso, como el enano de Benjamin que ahora ya no necesita de muñeco o disfraz alguno.

En efecto, el utopismo desde sus precedentes tempranos -Moro, Campanella, Bacon-supuso un movimiento decidido hacia el antropocentrismo, particularmente por el hecho de convertir en un problema político a resolver lo que antes era considerado voluntad divina o condición del destino. Una de las características modernas es que todos los problemas humanos se muestran como situaciones a resolver mediante la razón, lo cual supone arrebatar de la esfera divina la construcción de la sociedad. En ello radica la animosidad que la Iglesia mostró durante siglos ante los utopismos de diverso cuño, ya que lo que importaba aquí no era un diseño especifico de cómo debiera ser la sociedad, sino quién detentaba la función misma de modelarla. Esto se volvía más complejo en la medida que la Iglesia pretende tener un fundamento fuera de la Historia.

En un sentido inverso el avance de los diversos utopismos, como una fuerza secularizadora, contenía dentro de sí ciertos elementos religiosos. Por ahora avancemos algunos de ellos; la idea de redención que supone que la vida humana se transforma mediante la acción política de un modo ontológico, la distinción — parafraseando a Marx- entre un reino de la necesidad y otro de la libertad, lo cual nos lleva a dos formas diferentes de entender el sentido de la vida y, finalmente, la idea de revolución que contiene un aura apocalíptica ligada a un juicio definitorio de la Humanidad. Estos elementos pueden entenderse de modo secular, pero bajo ellos podemos reconocer la impronta religiosa que apela a poderosos sustratos emocionales que no pueden ser comandados por la estructura de poder de las religiones.

Recordemos que desde los primeros momentos del cristianismo existió una corriente utópica desarrollada en base al propio mensaje bíblico y que Bloch integra en la tradición del clasicismo utópico. Por ello la Iglesia no tuvo más remedio que reprimir el impulso que había creado propiciando las imágenes del Fin de los Tiempos y postergar por varios siglos la inminencia apocalíptica. Para conseguirlo monopolizó el recurso a la profecía que era un instrumento para dar profundidad o acercar el futuro con sus consecuencias emocionales y políticas. Como ya hemos indicado, la abundante presencia de los relojes en el arte renacentista denota la llegada de la melancolía como una nueva sensibilidad ante la caducidad temporal, que recae sobre todo lo existente y que convive con la fe en la eternidad cristiana. En esta iconografía tan reveladora, el reloj aparece junto a la guadaña como otro de los atributos de la muerte.

En el mismo centro de la Cristiandad, la Basílica de San Pedro, podemos observar el Mausoleo de Alejandro VI creado por Bernini. Allí la muerte es representada como un espectro esquelético, arropado con un manto que oculta su rostro, lo que parece querer indicarnos la imposibilidad de una visión completa de lo que se está manifestando. Sin embargo, podemos ver sus alas, que evocan la fascinación por los ángeles, ya sea los caídos o los leales. El paso inexorable de la arena en los relojes marca el fluir del tiempo como un recurso que se agota de modo irreversible y su consecuencia es el corte del hilo de la vida por la guadaña. Muerte y fin del tiempo se unen de manera indisoluble en estas imágenes y son muy evocadoras de lo que hasta hoy entendemos por el fin del tiempo y que resulta coherente con las imágenes de los relojes ya analizadas a propósito del grabado de Durero.

Como hemos dicho, la respuesta eclesial frente al desequilibrio y la tensión insoportable de la inminencia apocalíptica fue intentar desplazarlo al futuro, abstraerlo del presente y resituarlo en un tiempo difuso. El efecto indirecto es la melancolía que se 
extiende debido a la pérdida de la abstracción equivalente que supone la trascendencia como tiempo infinito. El férreo control de las profecías por parte de la Iglesia hizo que la elucubración sobre el futuro se deslizara a los horóscopos y la astronomía, que recibió un fuerte espaldarazo con el estudio verificable de los cometas. En efecto, el cielo revelaba fenómenos cíclicos, un cierto orden, que debería reflejarse en los asuntos humanos. Se produce una ampliación desde el conocimiento estrictamente sacerdotal y religioso al astronómico, que incluye nuevos actores y nuevos instrumentos que deben convivir por la presencia, aún asfixiante, del poder eclesial. Los astrólogos y astrónomos ocupan un lugar cada vez más relevante en la indagación del futuro, impulsados por el recurrente retorno de los miedos milenaristas. Tanto los lenguajes usados en la investigación de los cometas, como sus métodos, demuestran un aumento de la influencia de la ciencia en la búsqueda de las imágenes del futuro, traducibles en un avance de la secularización que tiene como ejemplo el trabajo de Laplace (Francescutti: 43).

Por su parte el utopismo también contenía una compleja dinámica propia de secularización. En efecto, el utopismo desarrolló desde sus inicios una dialéctica interna entre una formulación como discurso produciendo gran cantidad de obras hasta nuestros días, creando así el género literario de las utopías. El otro nivel de esta dialéctica es el impulso utópico que se alimenta de las imágenes bíblicas de las comunidades cristianas primitivas, sus figuras apocalípticas, mesiánicas y sus promesas que, aunque escatológicas, funcionan como un sedante frente al desamparo. Luego el impulso encuentra su forma más estable, como lo indica Mannheim, en las luchas campesinas del milenarismo, que asentó en las masas populares la idea de que era posible construir un orden secular de justicia cristiana. Dicha idea se convirtió en la convicción que se transmitió de generación en generación y sedimentó fuertemente en una específica forma de religiosidad popular. Como ya indicamos, aquello que los intelectuales discutían como teorías sobre la buena sociedad, las masas lo vivían como un problema de índole religiosa con poderosas implicancias emocionales. Lo que es relevante es que ambos niveles de esta dialéctica del utopismo funcionaron de manera interrelacionada para crear las abstracciones equivalentes que movilizaron la acción política durante los dos últimos siglos.

En estos fenómenos subyacía la grieta que el cristianismo oficial percibió claramente; que el reino milenario prometido tenía que arrasar con una realidad que se fundaba en Dios mismo. En cierto modo, el hombre aparecía como un actor que aceleraría la redención del mundo y en ese proceso se convertiría en sujeto de la historia. En consecuencia la utopía es un sueño cosmogónico en el ámbito de la historia ya que intenta «desfatalizar» el mundo, arrancar al hombre del campo oscuro y yermo del destino, quitarles a los dioses y los demonios su presa.

A partir de la Revolución Francesa las abstracciones equivalentes creadas por el utopismo fueron capaces de dar sentido a la vida de un modo más amplio a como la religión lo había hecho anteriormente, lo cual se radicalizó desde mediados del siglo XIX. Esto sin duda supuso una ampliación de la base secular de la política y fue esencial para el desarrollo de la democracia moderna. Sin embargo, el derrumbe del socialismo causó como efecto dominó la disolución de la URSS, el desfondamiento ideológico de la socialdemocracia así como el cuestionamiento de la ideas de igualdad, justicia y solidaridad, implicando al principio activo de la transformación social. En efecto, desde la caída del Muro de Berlín la idea de una melancolía de izquierda parece haberse reinstalado de manera poderosa como el talante emocional de la izquierda heredera del marxismo, convirtiéndose en categoría de análisis político.

Llegados a este punto vemos que la melancolía de izquierda es el producto de una crisis profunda de la modernidad que nos ha tocado vivir. En esta peculiar melancolía 
está presente el agobio y el aburrimiento profundo ${ }^{9}$ como males que involucran una dinámica de menosprecio del mundo, que nace de una «tristeza de lo presente». El bien contrario al aburrimiento es la capacidad de la conciencia de acoger hospitalariamente la otredad, desprovistos de lógicas de poder. El aburrimiento profundo es causado por esa impotencia de acoger, de liberarse del poder y se traduce en un horror de sí mismo, a causa de un tedio de los bienes internos de la propia conciencia.

El aburrimiento existencial aparece como una consecuencia no intencional de la intensa estructuración del mundo, que ha buscado eliminar las fuentes de incertidumbre, ambivalencia y azar. La conciencia moderna, al mirar en su entorno, lo que encuentra es la proyección de sí misma lo que le ha permitido — siguiendo a Bauman — crear una isla de regularidades en un mar de azar (1998: 278). Ello se experimenta actualmente como una cárcel donde la repetición de lo conocido es el precio para exorcizar las amenazas de la diferencia, cuestión sobre la que volveremos en detalle más adelante.

Todas estas cosas se conjugaban en la conciencia utópica que pretendía fundar un nuevo presente, pero sin tomar en consideración que su dialéctica interna contenía tanto un potencial de liberación como lógicas de poder renovadas. La formulación utópica se encuentra, por lo tanto, presa de múltiples relaciones de poder que tienden a transformarse en relaciones de dominación ${ }^{10}$. Todo se manifiesta como nuevo en la utopía. Muchas veces se ha señalado que no es posible dar una imagen completa de lo que sería una utopía, ya que el deseado salto ontogénico y filogenético que ésta implica convierte a toda imagen en un mal esbozo de lo que está por venir. No por nada el propio Marx se negó siempre a dar una imagen acabada de lo que sería el comunismo.

La utopía, como se acaba de indicar, pretende introducir la experiencia del acto original. Un ejemplo paradójico de las consecuencias que esta tendencia tuvo para la modernidad la podemos encontrar en Borges y su Utopía de un hombre que está cansado en donde la saturación de experiencias y conocimientos hace imposible experimentar lo inédito. El único camino se encuentra en el olvido que diluye el sedimento que la vida deja como pesada herencia, sólo así es posible volver a descubrir y asombrarse. Lo paradójico radica en que en esta peculiar obra las fronteras entre utopía y distopía se trastocan, ya que la vinculación entre recuerdo y justicia se quiebra modificando los esquemas tradicionales del utopismo, desembocando nuevamente en el nihilismo.

Aquí nuevamente emerge el problema religioso del utopismo que ya hemos observado a propósito de Melancolía I y que, quizás, nadie resumió de manera tan magistral este reclamo utópico y existencial frente al dios cristiano como Cioran cuando destacó

9 Ver en este punto el interesante libro de Humberto Giannini. Del bien que se espera y del bien que se debe. (1997). En esta obra Giannini desarrolla de manera significativa el tema del aburrimiento existencial que será de bastante utilidad en este análisis.

${ }_{10}$ Conviene recordar la distinción de Michel Foucault entre relaciones de poder y relaciones de dominación como dos esferas separadas con campos relativamente autónomos. Las relaciones de poder cubren un campo amplísimo de las relaciones humanas, exceden el plano político y el de las instituciones, reflejando un modo de existencia humana en planos múltiples; sexualidad, intersubjetividad, cotidianidad, economía, etc. Se definen por el deseo de dirigir los comportamientos de los otros siendo móviles, reversibles e inestables. Igualmente las relaciones de poder se ejercen sobre alguien que posee libertad y en virtud de ello puede resistirse. Como señala Foucault, así como en la sociedad están diseminadas las relaciones de poder están diseminadas también las semillas de libertad para oponerse a ellas. Las relaciones de dominación en cambio son relaciones de poder que se han bloqueado, volviéndose irreversibles, inmóviles y fijas haciendo casi imposibles las prácticas de la libertad. Por lo tanto, lo odioso son los estados de dominación y no las relaciones de poder que «...no son en sí mismas algo malo y de lo que haría falta liberarse; considero que no puede haber sociedad sin relaciones de poder, si se entiende por tales las estrategias mediante las cuales los individuos intentan conducir, determinar la conducta de los otros» (FouCAULt, M, La ética del cuidado de sí como práctica de la libertad 412. Igualmente; El sujeto y el poder 241). 
su incapacidad para dar cuenta de su propia creación, pero al mismo tiempo podíamos reconocernos en esa incapacidad por la relación que establecemos con nuestra propia vida como obra (Cioran, Historia y utopía 108). Ciertamente, dicho reclamo no forma parte de lo manifiesto en lo utópico, forma más bien parte de su inconsciente y de esa manera ha persistido. Más allá del irónico escepticismo que caracterizó a Cioran, los utopistas subsumieron la amargura de este reclamo infinito frente a Dios en el principio de la esperanza que encuentra su mejor exponente en Bloch.

\section{A MOdO DE CONCLUSIÓN. REPENSAR LA SUBJETIVACIÓN PARA SALIR DE LA MELANCOLÍA}

Lo que fue narrado durante siglos como el advenimiento triunfal de una sociedad que suponía un tránsito de carácter ontológico, se ha vivido en las últimas décadas como un fracaso colosal que aún busca una explicación cuestionando incluso la idea moderna del sujeto. Las abstracciones equivalentes que antaño dieron sentido a la vida adoptan la condición de fantasmagoría y su ausencia crea una percepción del tiempo como cerrado sobre sí al modo como se representa el ángel melancólico de Durero. La percepción de vivir en medio de espectros se acentúa por la necesidad de preservar una cierta pureza de la memoria que parece estar condenada al fracaso, ya que la memoria es por definición lo fugaz. La memoria es un proceso activo y radicalmente subjetivo, que se transforma, que supone valoraciones, puntos dinámicos de recuerdo y de olvido. Pero el deseo de una memoria infinita siempre ha sido parte del utopismo moderno y justamente es lo que aparece como necesario preservar desde el punto de vista de la melancolía de izquierda. La memoria infinita es la base de la posibilidad de la autotransfiguración y la última resistencia a la caída de la identidad. Allí radica el núcleo duro que asigna sentido y lugar en el mundo, posibilitando la solidez del sujeto.

Sabemos, recordando a Freud, que la persistencia de la melancolía se debe en gran medida a la conexión entre la propia proyección narcisista con los recuerdos y esperanzas puestas en el objeto, que en este caso resultan fundamentales para la construcción de la propia subjetividad. No se trata de que el sujeto se desprenda de la memoria en tanto que punto de contacto con aquello que prometía su transfiguración, sino que los puntos de contacto sean abordados persistentemente como un intento de retornar a un pasado que ya no existe. Ello conduce a un desarraigo existencial en medio de un presente indeseable y la resistencia a vivir un futuro que no será lo que se esperaba.

Como ya hemos indicado, el instrumento privilegiado para lograr ser sujeto en sentido fuerte es la razón puesta al servicio de la vida como proyecto. Son muchas las formas de narrar la formación del carácter de la modernidad, sin embargo aquí nos situaremos en la que nos entrega Dialéctica de la Ilustración. Fragmentos filosóficos de Horkheimer y Adorno. En dicho relato, los autores asimilan al sujeto moderno a Odiseo que, errante en el mundo, enfrenta sus diversas experiencias para templar su carácter y desplegar su subjetividad en plenitud. Su itinerario confirma la identidad moderna como una fuerza que, mediante la razón, intenta mantenerse inmutable ante el cambio. Lo peculiar es que la razón se entiende aquí como astucia. Por ello la modernidad constantemente mantiene una actividad reflexiva respecto del mundo creando las diferencias interiores que la impulsan al futuro.

Ahora veamos en detalle este itinerario. Horkheimer y Adorno señalan cómo en $L a$ Odisea (Canto XII) se muestra la interconexión entre mito, dominio y trabajo (1998: 85). La variedad de los peligros y las aventuras mortales que el sujeto debe sortear forman una ruta de unidad de la propia vida, de formación de identidad del sí mismo. La 
posibilidad de narrar la propia experiencia autoindividualizante muestra cómo se han formado y fortalecido las resistencias a las fuerzas disolventes de la vida natural.

Desde el punto de vista de la Ilustración el poema épico es una superación del mito, ya que lo refleja racionalizándolo. En efecto, la Ilustración, al definirse como pensamiento en permanente progreso, siendo al mismo tiempo crítica del poder y fundamentación de nuevas formas de racionalización de éste, supera las bases que le van permitiendo su despliegue. El momento ilustrado del mito, que en un momento le sirvió de apoyo, queda luego reducido por la construcción de un relato racionalmente más complejo, que lo subsume y relee. La Odisea representa para Horkheimer y Adorno un ejemplo paradigmático de las relaciones de superación ${ }^{11}$ del mito en el relato épico. Siguiendo a los autores es posible encontrar cinco características (1998: 100) de La Odisea que reflejan una inflexión de superación del mito que expresan las lógicas de despliegue del sí mismo como un sujeto en sentido fuerte.

Primero, la obra mencionada nos muestra un itinerario que señala el viaje como una experiencia formadora de la propia conciencia. Segundo, las aventuras muestran las tentaciones que distraen de la formación del sí mismo. Tercero, la autocomprensión de los sentimientos es fundamental en la construcción del sujeto ${ }^{12}$. Sólo de ese modo es posible establecer el imperio de la razón sobre las emociones. Cuarto, mediante la experiencia engañosa de la diversidad se mantiene la unidad del sí mismo que involucra el aprendizaje del control de la propia naturaleza. La diversidad impulsa a la disgregación, por medio de la ambivalencia y la promiscuidad, que sólo puede ser superada gracias al ejercicio de la templanza de dicha unidad. La dominación de los afectos es el dominio de la propia naturaleza, y si existe algo que pueda llamarse la venganza de la naturaleza, es la creencia de que está vencida. En el relato, la vida queda reducida a aventuras que son el entrenamiento para mantener la unidad en la diversidad. Quinto, el «órgano» para superar las aventuras es la astucia, como expresión privilegiada de la razón, representada en el ardid, el engaño. En efecto, se acata la ley del mito de tal manera que no se cumple y por lo tanto se le destruye (1998: 110).

La legitimidad de este modo de formación del sí mismo se basa en los peligros que el sujeto enfrenta y que le obligan a reducir el uso la razón al engaño. Se muestra también la vocación de soledad que conlleva la formación del sujeto que se relaciona con los demás en una dualidad amigos-enemigos ${ }^{13}$ y que, como veremos más adelante, se resuelve finalmente como melancolía. De este modo el viaje aparece como la manifes-

11 Es importante señalar que el uso del concepto de superación, tal como se emplea aquí no supone implicaciones teleológicas como en la tradición hegeliana y marxista. Sólo expresa un punto superior en una escala de complejidad racional, en que los puntos previos son subsumidos al modo de avances en esa complejidad. Tanto el carácter de necesidad, como la esperanza teleológica no están presentes, los puntos de superación no están encadenados por un vínculo ajeno a los intereses de las relaciones de poder en juego. Su elección es arbitraria y representan puntos estratégicos, desde la mirada de las acciones del poder, en un plano temporal y espacial no sometidos a reglas trascendentales, sino meramente a narrativas de trascendencia en lucha.

12 En un sentido diferente al que planteamos aquí, véase Buck-Morss (1992).

13 En el análisis de Bauman, la distinción amigo-enemigo se funda en la búsqueda incesante de eliminar la ambivalencia, intensificando las lógicas de clasificación y es una variación de la oposición interior-exterior, fundamental en la formación del sí mismo. Por ello esta distinción está inscrita ontológicamente en el sujeto fuerte (Modernidad y ambivalencia 92). Igualmente, la escena de las sirenas, en La Odisea, nos señala que la transición del lenguaje mítico al lenguaje racional implica una profunda secularización. En el primero, las palabras captan el dinamismo del ciclo de la naturaleza, entre los extremos de la totalidad como ciclo perpetuo y la particularidad del cambio sin fin de los sujetos individuales sometidos al ciclo. De este modo, en la naturaleza se produce el reflejo de la totalidad en la particularidad y viceversa. Allí se produce la identidad entre las cosas y las palabras, a diferencia del segundo, en que las 
tación de la desmesura, la voracidad de un sí mismo insuficiente que se lanza al mundo con una clara vocación de digerirlo, ya que no encuentra en sí los elementos necesarios para completar el círculo de su desarrollo; la afirmación del «Yo soy» como un absoluto.

De este modo, el sujeto fuerte al crear el impulso al futuro que ya hemos mencionado despliega su poder, pero crea así, sin quererlo, las diversas diferencias interiores de la modernidad. El momento de fractura de esas diferencias interiores se debe a la potencia de la imaginación utópica y su actividad ontopolítica que se convirtió en un sistema reflexivo de la modernidad. El utopismo, expresado como el impulso a la transformación social, ha sido también una matriz de aprendizaje para la vida que se ha roto. En efecto, ser una diferencia interior era una experiencia existencial profunda que mostraba un lugar en el mundo, un modo de vida que contenía un mandato de transformación de la realidad y de sí mismo. Esto llevaba implícito la tarea de un peculiar cuidado de sí que permite reinterpretar el llamado kantiano a ser modernos (Kant, 2013: 85). La ruptura de esta matriz de subjetivación produce una carencia existencial y la pérdida de herencia. Ésta se expresa en una ausencia de sentido que sólo puede ser llenada por el retorno de las imágenes utópicas.

Por ello la crisis de la subjetividad moderna tiene como elemento destacado la imposibilidad de articularse mediante un modo de vida semejante al de Odiseo. En efecto, la centralidad del poder en la formación del sí mismo que Horkheimer y Adorno destacan se ha vuelto inviable. Ya no es posible aspirar a esa coherencia totalitaria en que la razón subordina todos los elementos descartando la complejidad psíquica del propio sujeto. Por otra parte, como demuestra la trayectoria de Odiseo, la vida no puede ser vivida como una permanente lucha contra la propia naturaleza, así como tampoco en el enfrentamiento contra los demás. Menos aún puede negarse la importancia de los sueños como formadores de las diferencias interiores. En el caso planteado en Dialéctica de la Ilustración los sueños son negados como elementos irracionales que distraen al sujeto de su actividad propia o bien se les racionaliza de tal modo que pierden su potencia transformadora y por ende no son, en rigor, diferencias interiores. En un plano más general, Horkheimer y Adorno ligan el relato de Odiseo a una cultura de los señores y de la crueldad en el capítulo dedicado al Marqués de Sade. Esto es importante porque el utopismo tiene una dimensión completamente distinta, que se vincula con una empatía ampliada a la noción de la Humanidad, donde ya no puede haber señores. De ahí uno de los fundamentos del clasicismo utópico al cual ya hemos hecho referencia.

Esta trayectoria del sujeto moderno nos muestra que sus bases están socavadas porque la empatía por la Humanidad no logra cuajar como actividad ontolopolítica. El sueño fundamental del utopismo, presente de muchas formas en las diversas izquierdas, es justamente la redención de las víctimas de la historia frente a la cultura de los señores. Esto se vive tanto como herencia, mandato y elemento de autoformación que genera la posibilidad de enunciar un «nosotros». En efecto, el pensamiento de izquierdas supone la necesidad de soñar en común como base de la acción colectiva. En este sentido no hay contradicción entre lo colectivo y lo individual, ya que lo primero es un fuerte elemento de subjetivación que se encarna en ese «nosotros». Por otra parte este "nosotros» se plantea, por su universalismo ético, como una base de superioridad moral en la vida cotidiana, lo cual templa frente a la adversidad y permite distinguirse de otras opciones ideológicas. Como vemos, la dimensión subjetiva resulta esencial para comprender la importancia del soñar colectivo que implica el utopismo.

palabras en su labor de designación, transforman las cosas. En dicha transición se elimina la sacralidad de la palabra para que completamente racionalizada sirva de mejor manera como instrumento de poder. 
La condición espectral que adopta el utopismo - y que tiñe de melancolía al sujetoestá vinculada justamente con la privación de la herencia de los sueños, que durante siglos se han tejido de generación en generación. Derrida nombró este fenómeno como el aprendizaje de vivir rodeado de fantasmas («Exordio a los espectros de Marx»: 8), que en el mejor de los casos se comportan como compañeros y amigos que demandan una política de la memoria, de la herencia y que se afianza en la justicia, no en el derecho, que como indica Benjamin ya está asentado en cierta violencia fundacional ( Para una crítica de la violencia»). Los espectros son las víctimas de la historia, que tanto preocuparon a Bloch y a Benjamin, que se convirtieron luego en un centro ineludible para la teoría crítica y han sido fundamentales en las reflexiones de Zygmunt Bauman sobre el genocidio (Modernidad y Holocausto). En efecto, las víctimas se han vuelto espectros al igual que las imágenes utópicas que prometían su redención.

Sin embargo, la idea misma de redimir a las víctimas a través de la memoria se revela problemática, ya que como bien señaló Max Horkheimer a Benjamin, en una carta de 1937 citada por este último; «La injusticia pasada ha ocurrido y está cerrada. Los muertos han sido matados efectivamente...Si se toma la inconclusión completamente en serio, hay que creer en el juicio final»(Benjamin, 2000: 140). La única manera de sostener esta redención es mantener los residuos mesiánicos en el utopismo, que tan alto precio han cobrado por la esperanza proporcionada. Benjamin lo expresa con la siguiente claridad;

«El correctivo a estos cursos de pensamiento [lo recién señalado por Horkheimer] reside en la consideración de que la historia no es únicamente una ciencia, sino en grado no menor, una forma de la remembranza. Lo que la ciencia ha "establecido" puede ser modificado por la remembranza. La remembranza puede convertir lo inconcluso (la dicha) en algo concluido, y lo concluido (el sufrimiento) en algo inconcluso. Esto es teología; pero en la remembranza hacemos una experiencia que nos prohíbe concebir la historia de modo fundamentalmente ateológico, así como tampoco nos es lícito buscar escribirla en conceptos inmediatamente teológicos.» (Benjamin, 2000: 142)

Desde una perspectiva posmoderna el pasado está cerrado, y con él todo el inmenso sufrimiento que reverbera en la historia. La noción de redención — planteada por Benjamin - es en cierto modo idealista, y tiene toda la carga teleológica implícita del judeocristianismo. De este modo nos percatamos que las formas tradicionales de entender el utopismo no pueden cumplir su promesa de reintegrar a las víctimas a la Humanidad, como una noción superior donde se encuentran reconciliados los extremos del dolor y la plenitud, la víctima y su victimario. Desde el ángulo de la crisis del utopismo, y la melancolía de ella derivada, la situación espectral implica vivir entre el vértice desolador de la pérdida, la ausencia, y por otra parte el sueño de lo que hubiera podido ser. Vértice que Derrida señala como el de la vida y la muerte, donde quedamos atrapados como una situación intermedia en donde, al igual que los espectros, hay que aprender a vivir de un modo diferente, nuevo e incluso positivo (Derrida: 9) ${ }^{14}$.

La modernidad que nos ha tocado vivir, una modernidad entre muchas y demasiado incompleta, está permanentemente determinada por estas situaciones intermedias y espectrales, en que los vínculos de sentido que daban coherencia a la estructura del tiempo se han vuelto obsoletos. Por ello, la debilidad de la subjetividad supone la necesidad continua de restablecer los equilibrios existenciales en un mundo en que la intensidad del cambio ya no está relacionada con las narrativas de progreso. En efecto,

14 Desde otro ángulo ver los interesantes artículos de Charles Maier (1993) y YaEl Navaro-Yashin (2009) sobre políticas de la memoria. 
Odiseo, como expresión de la subjetividad fuerte remonta esta debilidad mediante la actividad incesante de la razón para mantener este equilibrio. Pero ya vemos la crisis de esta estrategia en el ángel melancólico de Durero al intuirse su insuficiencia. Por ello, llamar tardía a esta forma de modernidad tiene la ventaja de marcar precisamente su desplazamiento respecto de un proyecto inconcluso, al decir de Habermas. De este modo, el apelativo de posmodernidad se muestra tan antojadizo como un funeral antes que el enfermo exhale por última vez. Vivimos más bien una época posilustrada en que aún nos amparamos en los relatos generados por la Ilustración, pero sabiéndolos insostenibles en su pretensión de racionalidad trascendental. Más bien apelamos a ellos porque son el marco único y necesario en que se sostiene el fundamento de la democracia y la expansión de la igualdad y las libertades.

Ciertamente, lo anterior nos deja en una situación intermedia cargada de melancolía por la sensación de haber perdido esa abstracción equivalente que son los sueños utópicos. Por otra parte, la melancolía de izquierda incluye una nueva sensación de caducidad y fugacidad inscrita en el ámbito ontológico. Como ya se indicó, el relato de formación de la modernidad, basada en la matriz ilustrada, tiende a la inmutabilidad, que a su vez se fundamenta en la solidez ontológica, en la interpretación de la permanencia de los objetos y su estabilidad inherente en nuestros marcos categoriales. Por ello, las formas modernas de entender la trascendencia están emparentadas con la solidez ontológica. Lo anterior imposibilita la viabilidad de los relatos racionales de trascendencia tal como la modernidad los entendió en los actuales escenarios de nuestra cultura (Bauman, Modernidad líquida).

Por otra parte, cabe destacar que el estado de melancolía asociado a la figura de la muerte del utopismo, por lo menos en el sentido conocido hasta ahora, tiene como contexto inexorable el de la catástrofe. Es lo que Benjamin denominaba un estado de excepción que se ha convertido en la regla vinculada a la producción del progreso (Benjamin, 2000: 53). En efecto, la persistencia de la injusticia como un continuo histórico se ha convertido en norma de vida, la que se deriva del despliegue mismo del progreso, le es inherente siendo su anverso ambiguo e incierto. De este modo, la melancolía está encadenada a una muerte producida por medio de un crimen, no la muerte como parte de la «secuencia normal» de la propia condición natural. Por lo tanto, la muerte acontecida como catástrofe atrapa por medio de la melancolía que adopta el modo de una condena.

Es necesario, entonces, separar contundentemente estas dos formas de la melancolía; $1^{\circ}$._ la melancolía — analizada por Freud- como el estado de postración y sufrimiento derivado de la muerte de un ser querido o una «abstracción equivalente» —que no puede ser superada en el duelo- y $2^{\circ}$.- esta otra forma de melancolía sustancialmente distinta, en que tanto los seres queridos como las «abstracciones equivalentes»el utopismo en este caso- son literalmente destruidos en la confrontación política. En este segundo caso la pérdida no puede ser integrada en la comprensión emocional de los sujetos, porque dicho acontecimiento no cabe dentro de las lógicas predecibles, y por cierto inexorables, de los ciclos de vida y muerte. Ésta se presenta justamente como lo impredecible e increíble, lo inasimilable. Ronda permanentemente en ella tanto la convicción de la injusticia como la de los múltiples relatos posibles de cómo podría haber sido la vida sin dicha carencia. Y si bien estos procesos frecuentemente se convierten en la base del reclamo por la justicia, que en cierto modo es ya una salida del estado de melancolía, también se da el caso contrario donde se produce un encierro en ella.

Las abstracciones equivalentes que han sido derrotadas pierden su estatuto movilizador y articulador de sentido. Se retiran, desaparecen, su pulso se hace más lento pareciendo que entran en un estado de hibernación, en espera de tiempos mejores. Sin 
embargo, se vuelven más espectrales en tanto se cae en la cuenta, siguiendo a Freud, de que al parecer el objeto perdido no es fácilmente identificable. «Aquello» extraviado es la propia imagen de la redención, de la transmutación en alguien totalmente distinto. "Aquello», designado así por su carácter irrepresentable y al mismo tiempo distante, pero a su vez, paradójicamente íntimo al modo de una «diferencia interior» que se mantiene en el ámbito de la promesa, de la profecía, de algo que debe suceder y que no acontece. Pero conviene recordar que lo que se ha perdido, en realidad ha sido arrebatado por la derrota política que ha implicado costos inconmensurables de sacrificio y dolor. Por ende, la pérdida viene a verificar la idea de Benjamin de la historia como catástrofe.

La melancolía guarda esta tristeza por la añoranza de la promesa que se escapa en el tiempo. En esa añoranza se preserva la esperanza de verse a sí mismo reflejado en la trascendencia, más allá de toda limitación de la vida real. En efecto, la modernidad creó sus propias diferencias interiores — progreso, utopía, cambio social, revoluciones, etc.que le permitieron un dinamismo inusitado, su vocación de futuro y que la tensionaron y generaron sus contradicciones. Siguiendo este modelo, la melancolía moderna también ha producido sus diferencias interiores en las que la fantasía juega un papel muy importante. Freud describió la evolución de la fantasía como una resistencia a abandonar las fuentes de placer disponibles, lo que se enmarca en una tendencia del aparato anímico al ahorro de energías. Al cimentarse el principio de realidad, quedó el fantasear como una esfera independiente, que sólo se relaciona con el principio de placer por medio de los juegos infantiles y continúa luego en los sueños diurnos liberándose de la dependencia de los objetos reales. Incluso Freud agrega una metáfora muy significativa sobre la topografía de la imaginación, que es "como una nación cuya riqueza se basa en la explotación del suelo, pero que se reserva un terreno sin cultivar en estado natural y a salvo de las alteraciones de la cultura (Yellowstone park)» ("Formulaciones sobre los dos principios del acaecer psíquico» 227) ${ }^{15}$.

Extrapolando ese análisis al caso de las abstracciones equivalentes y sus relaciones estructurales con la modernidad, el espacio de la imaginación aparece como un territorio sin cultivar, lo cual no significa que dicho territorio imaginario no tenga un valor implícito en la circulación económica del deseo. Su sentido como diferencia interior es que, primeramente, sólo con su presencia logra una regulación del territorio ya colonizado y administrado; por ejemplo, en el sentido de la función negativa del utopismo señalada por Adorno (Horkheimer, Adorno: 91). En segundo término, este terreno, que en principio aparece como reserva natural puede tener una doble lectura: A) como reserva natural en el sentido que se le ha asignado una función de diferencia interior para que se convierta en una suerte de paradigma de la diferencia en medio de un universo racionalizado, y eventualmente en un punto de fuga ante el agotamiento de las posibilidades de dicho universo y B) como un terreno reservado que puede ser colonizado para enfrentar situaciones de crisis y, por lo tanto, aunque parezca un espacio desaprovechado, pertenece al ámbito de lo que está inventariado como un recurso disponible.

15 Ernst Bloch analiza este específico punto de la fantasía, como reserva natural sustraída al principio de realidad, que se manifiesta coactada y desvinculada de su relación con el futuro en el marco freudiano. Por el contrario, BцосH señala en el Principio esperanza que el «érase una vez permite vislumbrar en el fue una vez el será una vez» (Vol. I. 85). Lo anterior se expresa en los cuentos infantiles, que pretenden que los niños se identifiquen de modo narcisista con el protagonista y su final feliz, lo que aparece como el anuncio de una experiencia por venir. El cuento infantil, repetido muchas veces funcionaría como una profecía hecha al niño respecto de su propia utopía por alcanzar, lo que se revela como un proceso de formación del sí mismo. 
En la primera alternativa nos encontramos en una perspectiva weberiana, matizada por la teoría crítica, de la modernidad en que la jaula de hierro de la racionalización deja un espacio disponible para la diferencia, estableciéndose de este modo un principio de dinamismo. En nuestra situación dicho principio aparece fuertemente debilitado por la presión de la racionalización que pretende crear un mundo ontológicamente estable. Como destaca Bauman la modernidad intenta establecer una claridad sobre el mundo creando una estructura que rompa con el azar. "Estructura» significa, desde un punto de vista ontológico, monotonía de sucesos, repetición relativa lo que conduce a lo predecible en el ámbito epistemológico. La estructura conlleva que las probabilidades sean manejables haciendo más factibles las que se desean. De esta manera, el hábitat humano "estructurado" se convierte en la isla de regularidades en medio del mar de azar, aunque su efecto paradójico sea la construcción de nuevas formas de represión y aburrimiento existencial.

Actualmente el azar se nos manifiesta de una forma totalmente distinta a lo que se representaban con dicho término los utópicos de todo signo. Hoy, el azar nos muestra una cara amable en que su campo semántico derivado nos remite a las imágenes del juego, un cierto renacimiento de lo mágico, la posibilidad de la seducción de la diferencia. En definitiva, una ruptura o al menos una suspensión temporal de la intensiva racionalidad de la vida moderna con todo su agobio y estrés. El anverso del agotamiento de la racionalidad es la producción de sociedades opulentas que permiten una reducción sin precedentes en la historia humana de la pobreza, la enfermedad y la ignorancia, así como de formas muy rudimentarias, aunque no por ello menos dolorosas, de relaciones de dominación. Por supuesto, esto no quiere decir que la modernidad no esté sujeta a un proceso de ambivalencia que genera nuevas formas de incertidumbre y miedo.

Por su parte, los autores utópicos se enfrentaron con una noción de azar que justamente mostraba un lado bastante opuesto al que hoy experimentamos. El azar significaba, y es necesario señalar que para una parte muy importante de la humanidad sigue siendo de esta manera ${ }^{16}$, la indefensión frente al hambre, la miseria, la explotación y la enfermedad. La imposibilidad de asegurar las fuentes de sustento y evitar el sufrimiento era la cara horrenda del azar, que adoptaban la forma de destino ineludible y de la fatalidad. Esta diferencia en la percepción del contenido semántico del azar es imprescindible para medir con justicia los impulsos emancipadores de la modernidad.

Ciertamente puede indicarse que la construcción intensiva de islas de seguridad en un mar de azar ha derivado en el tono emocional melancólico y, por otra parte, tampoco dichas islas han sido capaces de proporcionar la seguridad moderna que se prometió. A modo de ejemplo cabe destacar el impacto que ha tenido en las últimas décadas la sociología del riesgo y particularmente la obra del recientemente desaparecido Ulrich Beck.

A pesar de todo ello, la modernidad ha creado modos de vida completamente nuevos y ha permitido importantes avances en el cuidado y protección de la vida. Lo que quisiéramos destacar es que la melancolía como nuevo espíritu de la modernidad es un estado propio de la condición posilustrada — nótese que no posmoderna- pero que necesariamente tiene un carácter transitorio. La condición espectral de la vida no es sostenible en términos culturales y las abstracciones equivalentes no han muerto del todo. Éstas se

16 En este sentido me parece de gran utilidad consultar la serie de los Informes de Desarrollo Humano que cada año son publicados, desde comienzos de la década de los noventa, por el Programa de Naciones Unidas para el Desarrollo. PNUD. Nueva York. Ediciones Mundi-Prensa. Los informes se encuentran disponibles en http://www.undp.org [acceso miércoles, 20 de enero de 2015] 
encuentran en un proceso de resignificación social que depende de lo que acontezca con la propia herencia ilustrada. Sabemos que dicha herencia se encuentra múltiplemente asediada, sin embargo, como ya se ha indicado ésta es el sostén de las libertades que aun ejercemos y de la propia democracia. La propia imagen de Durero es transitoria, en el sentido de que lo que vemos allí representado no puede ser un estado permanente, sino un momento previo a otro que desconocemos y que sólo puede resolverse por medio de la acción histórica de los ciudadanos modernos.

\section{RefEREnCias Bibliográficas}

Anderson, P., Consideraciones sobre el marxismo occidental, Madrid: Siglo xxI, 1979.

BADIou, A., De un desastre oscuro. Sobre el fin de la verdad del Estado. Madrid: Amorrortu, 2006.

Bauman, Z., Modernidad líquida, Buenos Aires: Fondo de Cultura Económica, 2002.

- Modernidad y ambivalencia, Barcelona: Anthropos, 2005.

- Modernidad y holocausto, Madrid: Sequitur, 1998.

Benjamin, W., «El autor como productor.» en: Benjamin, Walter, Iluminaciones 3: Tentativas sobre Brecht, Madrid: Taurus, 1975.

— «Informe sobre la literatura francesa.» New Left Review 51 (2008): 25-44.

- La dialéctica en suspenso. Fragmentos sobre la historia, Santiago: Universidad Arcis y LOM Ediciones, 2000.

— «Left-Wing Melancholy.» Screen 15.2 (1974): 28-32.

- «Para una crítica de la violencia.» en: Benjamin, Walter. Angelus Novus. Barcelona: Edhasa, 1971.

Bernstein, C.L., «A Surplus of Melancholy. The Discourse of Mourning in Freud, Benjamin, and Derrida.» Poligrafías. Revista de Literatura Comparada 3 (1998): 1-17.

Best, S., «On Failing to Make the Past Present.» Modern Language Quarterly 73.3 (2012): 453-474.

Bloch, E., El principio esperanza. 3 vols. Madrid: Aguilar, 1977-1980.

Borges, J.L., Utopía de un hombre que está cansado, Santiago: Editorial Andrés Bello, 1990.

Brown, W., Politics out of history,. New Jersey: Princeton University Press, 2001.

— «Resisting Left Melancholy» Boundary 26.3 (1999): 19-27.

Buck-Morss, S., "Aesthetics and Anaesthetics: Walter Benjamin's Artwork Essay Reconsidered.» Source, October 62 (1992): 3-41.

Dreamworld and Catastrophe: The Passing of Mass Utopia in East and West, MIT Press, 2000.

Origen de la dialéctica negativa. Theodor Adorno, Walter Benjamin y el Instituto de Frankfurt, Madrid: Siglo XxI, 1981.

Burton, R., Anatomía de la melancolía, Madrid: Alianza, 2006.

CAYGiLl, H., Walter Benjamin: the colour of experience, London: Routledge, 1998.

Cioran, E., Historia y utopía, Barcelona: Tusquets, 1995.

Constantinescu, D., «El infinito simbólico de la metáfora poética. Alberto Durero. Melancolía I.» Revista Disertaciones 2 (2011): 1-29.

DERRIDA, J., «Exordio a los espectros de Marx.» V.V.A.A., Espectros y pensamiento utópico, Santiago: Lom, 1998.

Dubiel, H., «Relections on intellectuals and the events of 1989. Beyond mourning and melancholy on the left» Praxis International 10:3/4. October 1990-January 1991 (1991): 241-249.

Erjavec, A., Postmodernism and the Postsocialist Condition. Politicized Art under Late Socialism, Berkeley: University of California Press, 2003.

Foucault, M., «El sujeto y el poder.» en: Dreyfus, Hubert y Paul Ravinov, Michel Foucault: Más allá del estructuralismo y la hermenéutica, México D.F : UNAM, 1998.

- «La ética del cuidado de sí como práctica de la libertad» en: Estética, ética y hermenéutica. Obras esenciales. Vol. III. Barcelona: Paidós, 1999.

FRANCESCUTTI, P., Historia del futuro. Una panorámica de los métodos usados para predecir el porvenir, Madrid: Alianza Editorial, 2003.

Freud, S., «Duelo y melancolía.» Obras completas. Vol. XIV. Buenos Aires: Amorrortu, 1991. 
— «Formulaciones sobre los dos principios del acaecer psíquico» Obras completas. Vol. XII. Buenos Aires: Amorrotu, 1991.

Fromm, E., Marx y su concepto del Hombre, México, DF.: Fondo de Cultura Económica, 2005.

García Selgas, F. y Serra, F., «La melancolía de la izquierda.» en: Selgas García, Fernando y Serra Francisco. Ensayos de filosofía social. Madrid: Libertarias Prodhufi, 1992.

Giannini, H., Del bien que se espera y del bien que se debe Santiago: Dolmen, 1997.

Gross, D. «Left Melancholy.» Telos 65 (1985): 112-121.

Gundermann, C., Actos melancólicos. Formas de resistencia en la posdictadura argentina, Buenos Aires: Viterbo, 2007.

Hall, S. «Vida y momentos de la primera Nueva Izquierda.» New Left Review 61 (2010): 163-182.

HorkHeImer, M. «Utopía.» en: Neusüss, Arnhelm, Utopía. Barcelona: Barral, 1971.

Horkheimer, M. y Adorno, T.W., Dialéctica de la Ilustración. Fragmentos filosóficos, Madrid: Trotta, 1998.

Jameson, F., Arqueologías del futuro, Madrid: Akal, 2009.

- El marxismo realmente existente. La Habana: Casa de las Américas, abril-junio de 1998.

JAY, M. «Once more an inability to mourn? Reflections of the left melancholy of our time» German Politics and Society, 27 (1992): 69-76.

KANT, I., ¿Qué es la Ilustración? y otros escritos de ética, política e historia, Madrid: Alianza, 2013.

Klibansky, R., Panofsky, E. y SaXl, F., Saturno y la melancolía. Madrid: Alianza, 1991.

Konder, L., Walter Benjamin: O marxismo da melancolía, Rio de Janeiro: Civilizaçao brasileira, 1999.

Little, A. «Democratic Melancholy: On the Sacrosanct Place of Democracy in Radical Democratic Theory» Political Studies 58 (2010): 971-987.

LöWY, M. y SAYRe, R., Rebelión y melancolía. El romanticismo como contracorriente de la modernidad, Buenos Aíres: Nueva Visión, 1992.

MAIER, C.S. «A Surfeit of Memory? Reflections on History, Melancholy and Denial» History and Memory 5.2 (1993): 136-152.

Mannheim, K. Utopía e Ideología. México D.F.: Fondo de Cultura Económica, 1993.

MarX, K. «Manuscritos económico-filosóficos.» en: Fromm, Erich, Marx y su concepto del hombre. México, D.F.: Fondo de Cultura Económica, 2005.

NAVARO-YASHIN, Y. «Affective spaces, melancholic objects: ruination and the production of anthropological knowledge» Journal of the Royal Anthropological Institute 15 (2009): 1-18.

NoRRIs, C. «Image and Parable: Readings of Walter Benjamin» Philosophy and Literature 7.1 (1983): 15-31.

Pensky, M., Melancholy Dialectics : Walter Benjamin and the Play of Mourning Critical Perspectives On Modern Culture, University of Massachusetts Press, 1993.

Real Academia Española, Nuevo tesoro lexicográfico de la lengua española (NTLLE). Ed. Real Academia Española. 23 de mayo de 2014. web. <http://www.rae.es/recursos/diccionarios/diccionarios-anteriores-1726-1992/nuevo-tesoro-lexicografico>.

SCRIBNER, C. «Left melancholy.» en: ENG, D L.: Kazajian, with an afterword of J. Butler, Loss. The Politics of Mourning. Berkeley: University of California Press, 2003.

Shulman, G., American Prophecy. Race and Redemption in American Political Culture. Minnesotta University Press., 2008.

Universidad de Santiago de Chile. USACH.

Christian Retamal

Christian.retamal@usach.cl

Christian.retamal.h@gmail.com

[Artículo aprobado para publicación en diciembre de 2015]. 